\title{
Applied phosphorus has long-term impacts on vegetation responses in restored jarrah forest
}

\author{
MI Daws University of Reading, UK \\ AH Grigg Alcoa of Australia Ltd, Australia \\ RJ Standish Murdoch University, Australia \\ M Tibbett University of Reading, UK
}

\begin{abstract}
Nutrient enrichment can result in long-term negative impacts on a range of native and semi-native plant communities worldwide. Despite this knowledge, fertiliser application is generally viewed as a necessary step in re-establishing native plant communities in post-mining restoration. However, long-term effects of nutrient addition to restored plant communities, particularly in native ecosystems that are adapted to inherently low-nutrient soils, have received little attention. Here we report results of two experiments run for 15 and 20 years, respectively, to investigate the effect of applied P fertiliser on responses of Eucalyptus marginata (jarrah) forest re-sprouter understorey species in sites restored after bauxite mining in Western Australia. Re-sprouter species are abundant in unmined forest but are under-represented in restored sites. At the end of the two experiments (i.e. after 15 and 20 years), the abundance of three groups of re-sprouter understorey species was reduced, compared with the zero-fertiliser treatment, when $P$ fertiliser was applied at rates from 20 to $120 \mathrm{~kg} \mathrm{P} \mathrm{ha}^{-1}$. In both experiments, the cover associated with $P$ responsive legumes increased with increasing $P$ application rates. This result suggests that when fertiliser is applied, slowgrowing re-sprouter species are susceptible to being outcompeted by more vigorous understorey species. Consequently, if the goal of restoration is to re-establish a diverse plant community, then minimising fertiliser application rates may be appropriate.
\end{abstract}

Keywords: Acacia, competition, fertiliser, legumes, nitrogen

\section{Introduction}

There is a well-established link between plant community composition and soil nutrient availability (e.g. Grime 1979; Gough \& Marrs 1990). Thus, variations in N and P supply have been linked to patterns of floristic diversity in ecosystems including tropical rain forest, temperate grassland and Mediterranean-type ecosystems (Wassen et al. 2005; John et al. 2007; Prober \& Wiehl 2012). In ecosystems with inherently low levels of soil fertility, elevated $\mathrm{N}$ and $\mathrm{P}$ levels may increase invasion by non-native species (Prober \& Wiehl 2012) or alter competitive dynamics among native species (Daws et al. 2015). Therefore, while nutrient availability is important for supporting plant growth and establishment, there is a need to understand its effects on resulting plant community composition in restored landscapes (e.g. Standish et al. 2008, 2010; Garcia-Palacios et al. 2010; Soliveres et al. 2012).

Fertiliser addition is generally viewed as a key step in the restoration of native plant communities following mining because it can stimulate plant growth and help initiate nutrient cycling processes (Grant et al. 2007; Williamson et al. 2011; Zipper et al. 2011; Ortiz et al. 2012). Fertiliser may help compensate for the loss of nutrients associated with the removal of vegetation and leaf litter prior to mining. In addition, delays in the spreading of topsoil for restoration (i.e. stockpiling), mixing of topsoil and subsoil, and using low-nutrient substrates in mine restoration (e.g. waste rock) can impact nutrient availability for plants (Short et al. 2000; Grant et al. 2007). 
A strategy commonly applied in parallel with fertiliser application (especially $\mathrm{P}$ ) is to plant or seed fast-growing legumes to restore productivity and re-establish nutrient cycling processes (e.g. Ward et al. 1990). Restoring $\mathrm{N}_{2}$-fixing legumes has the advantage of potentially increasing soil-N availability to other species such as trees. Fast-growing legumes may also reduce erosion of newly rehabilitated (bare) sites (Ward et al. 1990). This strategy has been widely applied in Australia (Langkamp et al. 1979; Todd et al. 2000; Grant et al. 2007; Brady \& Noske 2010) and elsewhere (Bradshaw 1983; Parrotta \& Knowles 1999, 2001). Legume growth and $\mathrm{N}$ fixation can also be maximised by applying $\mathrm{P}$ fertiliser to low-P soils since legumes are generally $\mathrm{P}-$, but not $\mathrm{N}$-limited. For example, adding the equivalent of $50 \mathrm{~kg} \mathrm{P} \mathrm{ha}^{-1}$ to mined and restored (Eucalyptus marginata) jarrah forest soils increased annual $\mathrm{N}$ fixation by Acacia pulchella from 12 to $85 \mathrm{~kg} \mathrm{~N} \mathrm{ha}^{-1}$ (Hingston et al. 1982).

There are, however, a number of potential disadvantages to restoration strategies based on establishing leguminous species and/or the use of high fertiliser application rates. These include increased competition due to the rapid growth and dense vegetation that can result (Koch 1987); elevated fuel loads, particularly for fine fuels from both live and senesced legumes (Todd et al. 2000; Grant et al. 2007); and many legumes produce a thick leaf litter layer that can physically retard the establishment of other understorey species (Boyes et al. 2011; le Stradic et al. 2014). While applying fertiliser, and particularly P, maximises early growth of legume species, it can also negatively impact on the re-establishing plant community. For example, elevated $\mathrm{P}$ can favour annual species, including weeds, while negatively affecting slow-growing species and those with specialised P-acquisition strategies, such as Proteaceae (e.g. Lambers et al. 2008; Shane et al. 2004). For example, in fynbos restoration after a simulated mining disturbance, Holmes (2001) found that adding $26 \mathrm{~kg} \mathrm{P} \mathrm{ha}^{-1}$ increased overall plant density and cover. However, this effect was mainly limited to exotic weeds, and P addition increased the mortality of native Proteaceae. Similarly, Daws et al. $(2013,2015$, 2019) found that for jarrah forest restored after mining, while applied $N$ had little effect on understorey plants, annual species (weeds and natives) were the main beneficiaries of applied P fertiliser. Furthermore, while the growth and density of native Proteaceae was insensitive to $P$ application, the overall species richness of native species was reduced at $P$ application rates greater than $20 \mathrm{~kg}^{-1}{ }^{-1}$ (Daws et al. 2013). Overall, these studies highlight the need for more detailed understanding of the combined effects of $P$ fertiliser and legumes.

The jarrah forest of Western Australia is a biodiversity hot spot with an estimated 300-400 understorey plant species occurring in areas impacted by mining for bauxite (Koch 2007). In addition, the soils of the jarrah forest are naturally deficient in P with levels of Colwell (available)-P typically being around $2 \mathrm{mg} \mathrm{kg}^{-1}$ (Hingston et al. 1982; Standish et al. 2008). Consequently, many of the plant species in the jarrah forest have specialised adaptations for $\mathrm{P}$ acquisition (Lambers et al. 2008). A significant proportion of these species are rushes, sedges and other grass-like species such as grass trees. These species are ubiquitous in the jarrah forest and by being able to re-sprout, are important for resilience following disturbance, such as fire and grazing. However, despite being abundant in unmined forest these re-sprouter species (sensu Bell 2001) are poorly represented in restored sites (Koch et al. 2004; Norman et al. 2006). Low seed production is likely to contribute to this finding. Additionally, P fertiliser rates of between 20 and $80 \mathrm{~kg} \mathrm{ha}^{-1}$ have been routinely applied in jarrah forest restoration following bauxite mining (Standish et al. 2015). Consequently, the low abundance of these species in restored sites may result, at least in part, from either direct toxicity of applied $P$ (Lambers et al. 2008) or, due to their inherently low growth rates (Pate et al. 1990; Bowen 1991; Koch et al. 2004), they may simply be outcompeted by fast-growing P-responsive species (e.g. legumes).

While we have reported previously on the effects of both competition from large understorey legumes and/or applied P on jarrah forest restoration (Daws et al. 2013, 2015, 2019), these studies focused primarily on responses at the community and growth-form level (e.g. species richness, density and cover over weeds, ephemerals, and re-sprouters). However, in this study, we report the effects of fertiliser $\mathrm{P}$ application in combination with the effect of legume density on the abundance and cover of three specific understorey resprouter taxa (Lomandra spp., Thysanotus thyrsoideus and Xanthorrhoea spp.) in bauxite mine restoration in the jarrah forest of Western Australia. In the first experiment, we assessed the responses of these taxa 20 years after the experiment was established. Specifically, we assessed the effects of three $P$ application rates 
$\left(0,80\right.$ and $\left.120 \mathrm{~kg} \mathrm{P} \mathrm{ha}^{-1}\right)$ on the abundance of these taxa, and the growth response of understorey legumes. In the second study, we report the effects of three fertiliser $P$ application rates $\left(0,20\right.$ and $\left.80 \mathrm{~kg} \mathrm{ha}^{-1}\right)$ on the same taxa, but after 15 years. In this study, P-application rates were combined with direct manipulation of the density of $P$ responsive legumes to assess if competition from legumes contributes to the observed responses of the re-sprouter species. Using these data, we test the hypotheses that soil $\mathrm{P}$ remains elevated for up to 20 years after a single initial fertiliser application; that applied P will increase the percentage cover associated with large understorey legumes; by increasing the competitive environment in the understorey, applied $\mathrm{P}$ will reduce the abundance of the three study re-sprouter taxa; and that these negative effects of $\mathrm{P}$ fertiliser on slow-growing species will continue to be evident even after 20 years.

\section{$2 \quad$ Materials and methods}

\subsection{Study site and species}

The experiments were established within the Alcoa of Australia Ltd bauxite mining lease in the northern jarrah forest, located between 60 and $100 \mathrm{~km}$ southeast of Perth, Western Australia. The area has a Mediterranean climate with cool, wet winters and hot, dry summers. Annual rainfall is $\sim 1,200 \mathrm{~mm}$ with average summer maximum temperatures of $29^{\circ} \mathrm{C}$ and average winter minimum temperatures of $6^{\circ} \mathrm{C}$ (Australian Bureau of Meteorology 2015).

The forest vegetation is comprised of the dominant overstorey species Eucalyptus marginata (jarrah), which constitutes around $80 \%$ of stems in both restored and unmined forest (Daws et al. 2015). The remaining stems are mostly comprised of the subdominant species Corymbia calophylla. In addition, there is a mid-storey layer dominated by Banksia grandis, Allocasuarina fraseriana and Xanthorrhoea preisii with large woody shrubs of Bossiaea aquifolium, various Acacia species and a diverse understorey (Gardner \& Bell 2007).

In both experiments we assessed the effect of applied $\mathrm{P}$ on the abundance of three re-sprouter taxa: Lomandra spp. (Asparagaceae), Thysanotus thrysoideus (Asparagaceae) and Xanthorrhoea spp. (Xanthorrhoeaceae). These taxa were chosen based on their being relatively abundant across both experiments. In addition, Lomandra spp. and Xanthorrhoea spp. are under-represented in restored sites compared with unmined forest (Koch et al. 2004; Norman et al. 2006; Koch 2007). Thysanotus thrysoideus is a perennial herb with a similar growth habit to Lomandra spp. and Xanthorrhoea spp. A suite of Lomandra species were aggregated together in this study due to individual species being at low abundance. The two Xanthorrhoea species found in restored sites ( $X$. gracilis and $X$. preissi) were aggregated due to difficulties in identifying the individual species in the field.

\subsection{Experiment 1}

The experiment was established in four newly restored mine pits. Treatment plots of $25 \times 25 \mathrm{~m}$ with an additional untreated $1 \mathrm{~m}$ strip between plots were established at each replicate site using a randomised complete block design and seeded during summer 1994 (January to April) with $1.44 \mathrm{~kg} \mathrm{ha}^{-1}$ Eucalyptus marginata seed, $0.60 \mathrm{~kg} \mathrm{ha}^{-1}$ Corymbia calophylla seed and an understorey seed mix containing $0.72 \mathrm{~kg} \mathrm{ha}^{-1}$ legumes and $0.197 \mathrm{~kg} \mathrm{ha}^{-1}$ non-legume species (Lockley \& Koch 1996). Fertiliser was broadcast by hand on a single occasion at rates of 0,80 and $120 \mathrm{~kg} \mathrm{ha}^{-1}$ for $\mathrm{P}$ and $80 \mathrm{~kg} \mathrm{ha}^{-1}$ for $\mathrm{N}$ and not incorporated into the soil. Thus, there were three fertiliser combinations. Phosphorus was applied as double superphosphate, and nitrogen as ammonium sulphate. 


\subsection{Experiment 2}

In March 2001, within each of six newly restored mine pits, a block containing six $40 \times 50 \mathrm{~m}$ plots was established. A factorial design with two factors was used: with and without seeding of seven large understorey legume species; and P fertiliser application, including none, 20 and $80 \mathrm{~kg}$ elemental $\mathrm{P}$ ha ${ }^{-1}$. Previous studies have shown that including or excluding large understorey legumes from the seed mix results in differences in the abundance and cover of these species (Daws et al. 2015, 2019). As a consequence, seeding large legumes results in more competition among understorey species for water. Each experimental plot also received a generic seed mix containing seeds of 108 jarrah forest species which was broadcast by hand in March 2001. This mix included the dominant tree species Eucalyptus marginata. After seeding, fertiliser containing $\mathrm{P}$ as di-ammonium phosphate, and $\mathrm{N}$ (as urea) was broadcast by hand onto each plot at an application rate of $80 \mathrm{~kg}$ elemental $\mathrm{N} \mathrm{ha}^{-1}$. Further details of the experimental design are provided in Daws et al. $(2015,2019)$.

\subsection{Botanical sampling}

In both experiments, a $20 \times 20 \mathrm{~m}$ plot was established within the centre of each treatment plot. Each $20 \times 20 \mathrm{~m}$ plot was further divided into twenty $2 \times 2 \mathrm{~m}$ quadrats with a total of $80 \mathrm{~m}^{2}$ sampled per plot. Species identity, density and percentage cover (a visual estimate that included overhang) were recorded separately for each $2 \times 2 \mathrm{~m}$ quadrat with density summed for the entire plot. The estimates of percentage cover took into account vertical structuring of the vegetation, such that the sum of all cover estimates could exceed 100\%. For Experiment 1, plots were monitored in 2014 (20 years after establishment of the experiment), and for Experiment 2 plots were monitored in 2006 and 2015 (5.5 and 15 years after establishing the experiment).

\section{$2.5 \quad$ Soil sampling}

For Experiment 1, soil samples were collected 13 and 20 years after the experiment was established. For Experiment 2, soil samples were collected three months after the experiment was established, followed by sampling at five and 17 years. For all soil sampling, six samples were collected from random locations at a depth of $0-10 \mathrm{~cm}$ in the furrow of the rip-lines in each plot and mixed. Soil was air-dried at $26^{\circ} \mathrm{C}$ and gravel removed using a $2 \mathrm{~mm}$ sieve (Rayment \& Higginson 1992). Samples were analysed at a commercial laboratory (CSBP Soil and Plant Laboratories, Bibra Lake, Australia) assessing Colwell (available) phosphorus (Colwell 1963).

\subsection{Statistical analyses}

For each taxa, one-way analysis of variance (ANOVA) followed by Tukey's post hoc test, implemented in Minitab 11, was used to test for differences in plant density and legume cover in relation to $P$ application rate (Experiment 1). For Experiment 2, two-way ANOVA was used to assess the effect of both $P$ application rate and the inclusion of large understorey legumes in the seed mix on plant density. Data did not require transformations to meet the normality and homogeneity of variance assumptions for ANOVA.

\section{$3 \quad$ Results}

\subsection{Soil Colwell P}

Combining the data from across the two experiments, the initial (single) application of $P$ fertiliser resulted in an increase in available (Colwell) soil $\mathrm{P}$ concentrations, with the concentration related to fertiliser application rate (Figure 1). Soil $\mathrm{P}$ concentrations declined over time; but even after 20 years, soil $\mathrm{P}$ at the two higher application rates ( 80 and $120 \mathrm{~kg} \mathrm{ha}^{-1}$ ) was elevated compared with the control (Figure 1). 


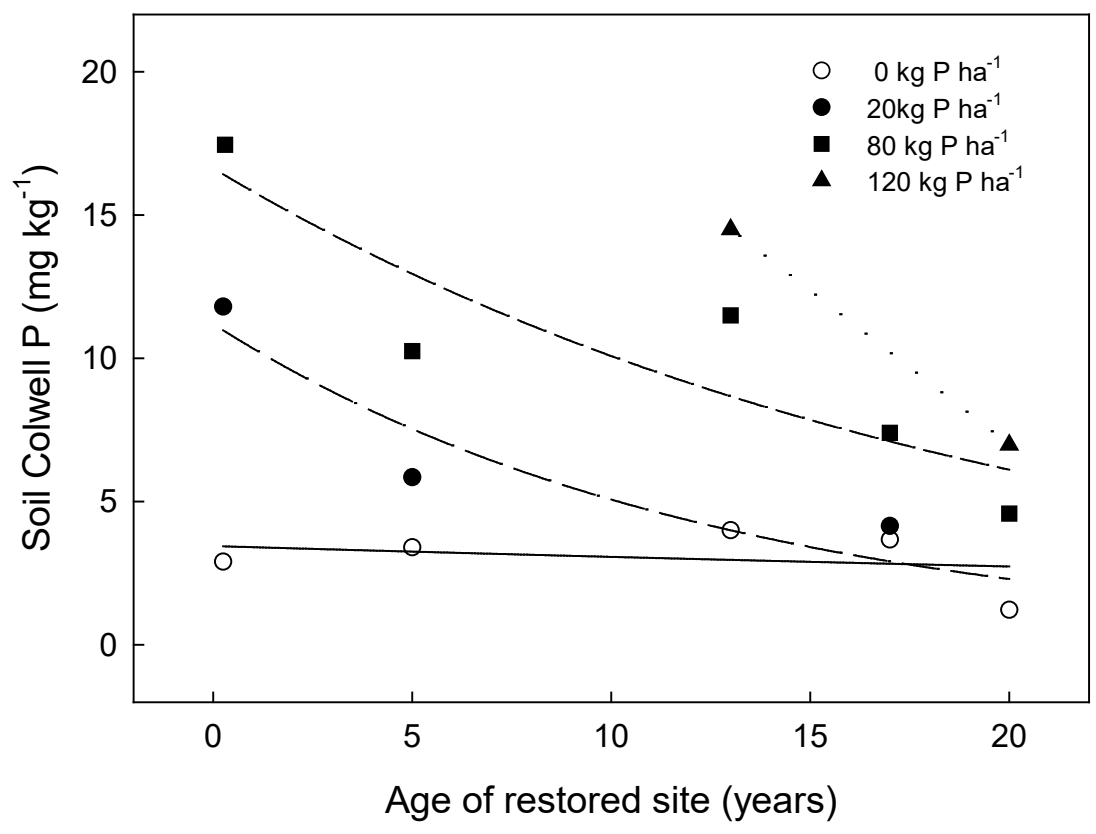

Figure 1 Changes in soil available (Colwell) $\mathrm{P}$ concentrations at $0-10 \mathrm{~cm}$ depth in restored jarrah forest in relation to $P$ application rate and time since application. The solid line refers to Colwell $P$ in the control treatment.

\subsection{Experiment 1 effect of applied $P$}

In 20-year-old restored sites, the abundance of all three re-sprouter taxa was significantly higher at $0 \mathrm{~kg} \mathrm{P} \mathrm{ha}^{-1}$ compared with their abundance at higher $P$ application rates (Tukey's post hoc test, $P<0.05$; Figure 2 ). For example, the abundance of Lomandra spp. declined from approximately 0.12 plants $\mathrm{m}^{-2}$ to approx. $0.01 \mathrm{~m}^{-2}$ and the abundance of $T$. thyrsoideus declined from 0.37 to 0.06 plants $\mathrm{m}^{-2}$ as the $\mathrm{P}$ application rate increased from 0 to $120 \mathrm{~kg} \mathrm{ha}^{-1}$. Conversely, as the $\mathrm{P}$ application rate increased, the cover associated with legume species increased from approximately 5 to $14 \%$ (Figure 2).

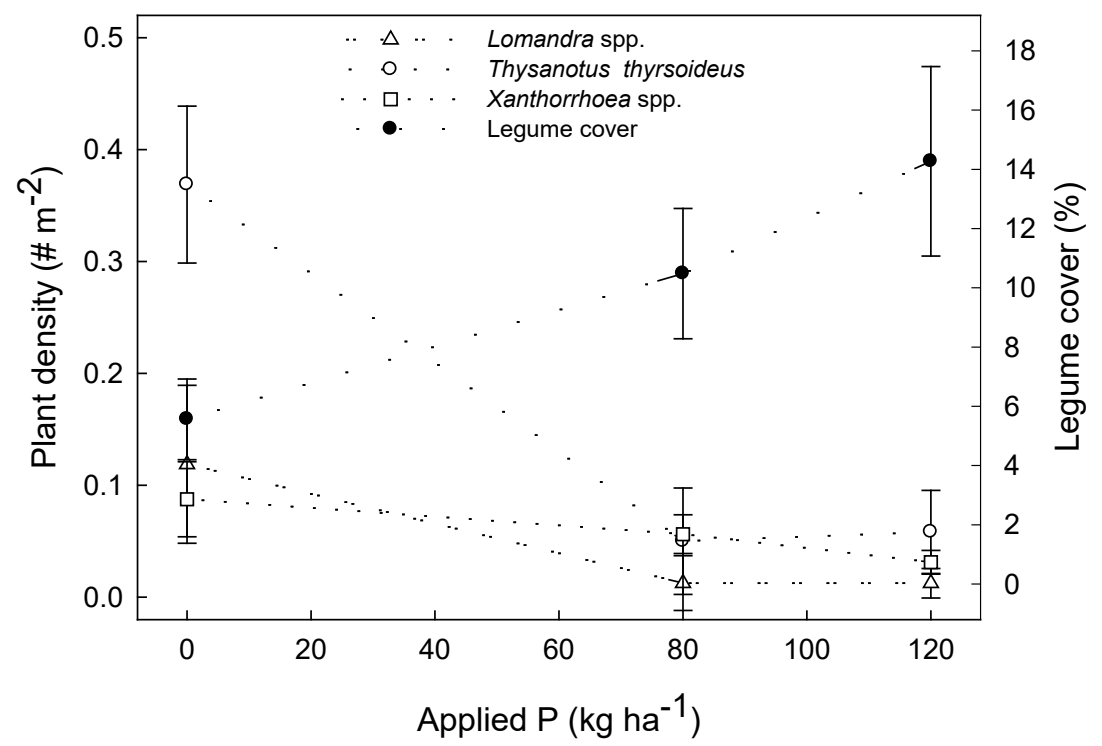

Figure 2 Effects of three $P$ application rates $\left(0,80\right.$ and $\left.120 \mathrm{~kg} \mathrm{ha}^{-1}\right)$ on the abundance of three groups of re-sprouter species in 20-year-old restored sites. Also shown is the plant cover attributable to legumes in this experiment (Experiment 1). Data are means $\pm 1 \mathrm{SE}$. 


\subsection{Experiment 2 effect of applied $\mathrm{P}$ and large legumes}

Five and 15 years after the single application of $P$ fertiliser, the effects on legume cover were still evident; legume cover responded positively to increasing $\mathrm{P}$ application rates (Table 1). However, legume cover was consistently lower at 15 years of age compared with five years of age. At both monitoring intervals, the percentage cover of non-legume understorey species was negatively affected by both seeded large understorey legumes and by applied $P$ fertiliser, such that after 15 years, non-legume plant cover was highest when neither additional large legumes nor $\mathrm{P}$ fertiliser had been applied (Table 1). Combined with a reduction in legume density between five and 15 years, these effects resulted in total plant cover also being highest in the absence of $P$ fertiliser and when large legumes were not seeded (Table 1).

Table 1 The effect of $\mathrm{P}$ application rate and seeding large understorey legumes on the cover of both legume species and native non-legume species. Results are shown for both five and 15 years after a single initial application of $P$ fertiliser. The shaded cells refer to the highest observed values, after 15 years, for both the cover of non-legume species and total cover

\begin{tabular}{|c|c|c|c|c|c|c|c|}
\hline \multirow{2}{*}{$\begin{array}{l}\text { Time } \\
\text { (years) }\end{array}$} & \multirow{2}{*}{$\begin{array}{l}\text { P treatment } \\
\left(\mathrm{kg} \mathrm{ha}^{-1}\right)\end{array}$} & \multicolumn{3}{|c|}{ Large legumes not seeded } & \multicolumn{3}{|c|}{ Large legumes seeded } \\
\hline & & $\begin{array}{l}\text { Legume } \\
\text { cover (\%) }\end{array}$ & $\begin{array}{l}\text { Native } \\
\text { non-legumes } \\
\text { (\%) }\end{array}$ & $\begin{array}{l}\text { Total } \\
\text { cover (\%) }\end{array}$ & $\begin{array}{l}\text { Legume } \\
\text { cover (\%) }\end{array}$ & $\begin{array}{l}\text { Native } \\
\text { non-legumes } \\
\text { (\%) }\end{array}$ & $\begin{array}{l}\text { Total } \\
\text { cover (\%) }\end{array}$ \\
\hline \multirow[t]{3}{*}{5} & 0 & 17.9 & 18.1 & 36.0 & 23.7 & 16.6 & 40.3 \\
\hline & 20 & 21.3 & 14.0 & 41.3 & 33.7 & 12.4 & 46.1 \\
\hline & 80 & 28.0 & 10.8 & 38.8 & 50.8 & 5.4 & 56.2 \\
\hline \multirow[t]{3}{*}{15} & 0 & 11.5 & 42.7 & 54.2 & 8.5 & 32.4 & 40.9 \\
\hline & 20 & 9.3 & 23.7 & 33.0 & 16.7 & 27.8 & 44.5 \\
\hline & 80 & 10.6 & 22.9 & 33.5 & 17.6 & 25.1 & 42.7 \\
\hline
\end{tabular}

Fifteen years after establishment of Experiment 2, increasing rates of applied $\mathrm{P}$ resulted in a significant reduction in the abundance of $T$. thyrsoideus and Xanthorrhoea spp. $(P<0.05)$, but not Lomandra spp. $(P>0.05)$. For example, in the no additional legumes treatment, the density of $T$. thyrsoideus declined from approximately 0.13 to 0.01 individuals $\mathrm{m}^{-2}$ as applied $P$ increased from 0 to $80 \mathrm{~kg} \mathrm{ha}^{-1}$ (Figure 3 ). Including large legumes in the seed mix also reduced the abundance of all three taxa $(P<0.05$; Figure 3$)$. 


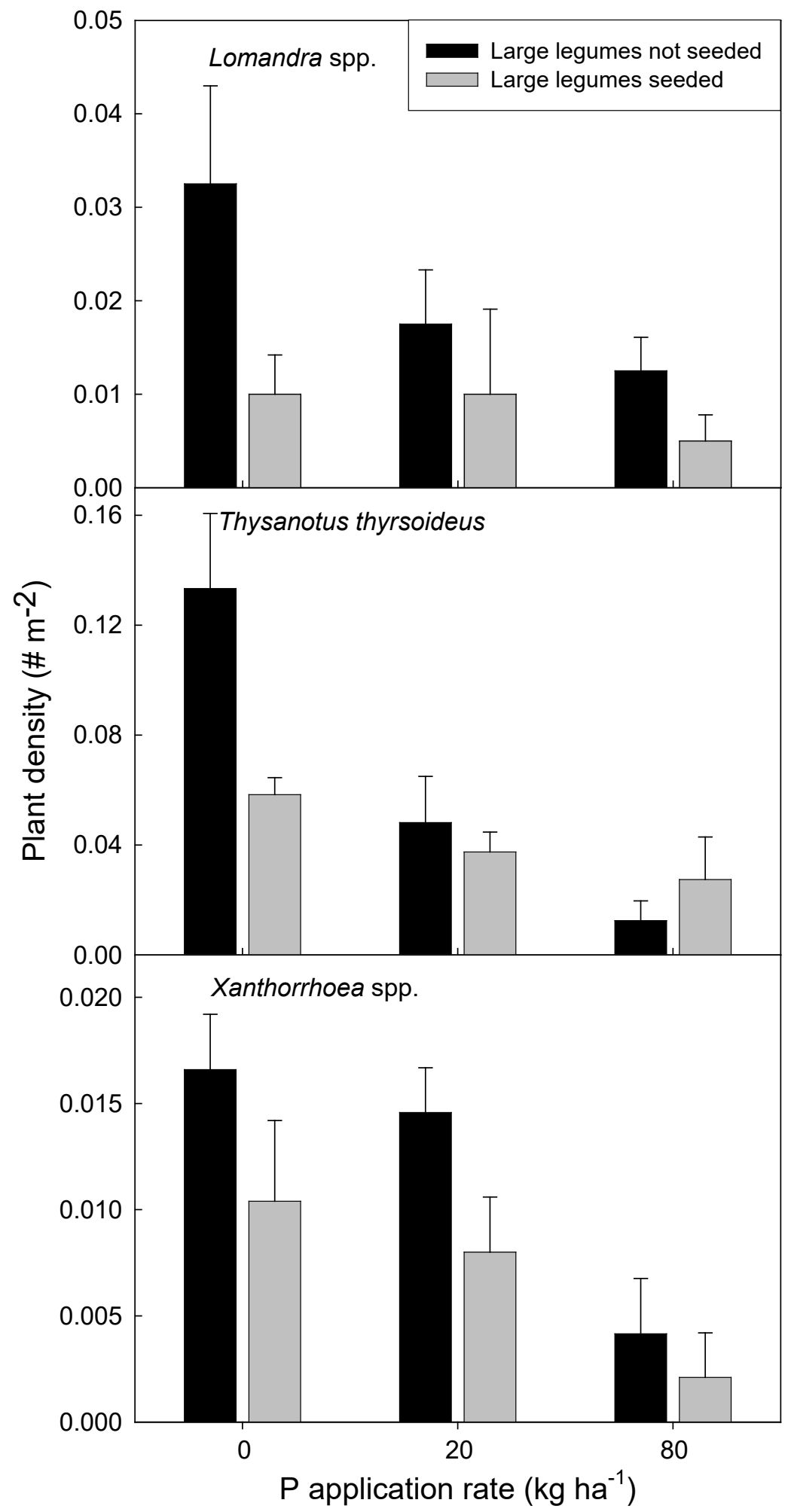

Figure 3 The effect of initial $\mathrm{P}$ application rate and seeding large legumes on the abundance of three re-sprouter taxa 15 years after a single initial application of $\mathbf{P}$ fertiliser (Experiment 2). Data are means $\pm 1 \mathrm{SE}$.

\section{Discussion}

Our data indicate that even 20 years after a single initial application of $P$ fertiliser, soil Colwell $P$ remains elevated and, therefore, potentially impacting vegetation responses. While overall soil $P$ levels declined over the duration of these two studies, even after 20 years soil $P$ was still higher than the approximately $2 \mathrm{mg} \mathrm{kg}^{-1}$ 
P typical of undisturbed jarrah forest soils (Standish et al. 2008). These findings are consistent with other studies of soil $P$ levels in restored jarrah forest, and other post-mining environments, which can remain elevated for at least 26 years after fertiliser addition (Spain et al. 2006, 2015; Banning et al. 2008; Standish et al. 2008). Indeed, a recent study of forest soil $P$ dynamics in a restored tropical eucalypt forest found ongoing net increases in near-surface concentrations of $\mathrm{P}$ over 26 years, potentially storing up future difference between fertilised restored and native forest systems (Spain et al. 2015).

Across both our experiments, applied P continued to benefit legume growth (as assessed by cover) after 15 and 20 years, although legume cover declined in Experiment 2 between five and 15 years (and presumably also over the duration of Experiment 1). Many fast-growing legumes senesce over time reaching a maximum cover at approximately five years of age and declining thereafter (Grant et al. 2007; Daws \& Koch 2015). These observations have contributed to the seeding strategy for jarrah forest restoration because it has been assumed that large legumes will be replaced by other species as succession proceeds. However, our data suggest that legumes comprise a significant portion of total plant cover in restored jarrah forest communities at five, 15 and 20 years of age. So, on the one hand these data suggest that if the desired goal of restoration is to rapidly (within five years) establish plant cover (e.g. to minimise the risk of erosion), seeding large legumes combined with applying $P$ fertiliser can be an effective strategy. However, our data also show that maximum plant cover can be achieved in time (at 15 to 20 years) when large legumes are not seeded and $P$ fertiliser is not applied.

We also found that the abundance of the three re-sprouter taxa that we investigated declined with increasing soil $P$. One potential explanation of these negative effects of $P$ application is the direct toxicity of applied $P$; many species in the jarrah forest (e.g. Proteaceae) have specialised adaptations for $\mathrm{P}$ acquisition in this naturally P-deficient system (Lambers et al. 2008; Shane et al. 2004) and have limited ability to regulate $P$ uptake when P supply is increased (Shane et al. 2004; de Campos et al. 2013; Handreck 1991; Lambers et al. 2002). However, the results of Experiment 2 (Figure 3) indicate that at least a portion of the decline in abundance of the re-sprouter species at elevated $\mathrm{P}$ can be directly attributed to the abundance of large understorey legumes and not elevated soil $P$ per se. Further study is required to assess the relative importance of direct toxicity of elevated soil $\mathrm{P}$ compared with competitive effects for restoration outcomes in the jarrah forest.

Both experiments indicate a negative effect of legumes on the abundance of re-sprouter species mediated by $\mathrm{P}$ application rate. While we are unable to determine if the relationship is causal for Experiment 1 , Experiment 2 indicates that there is causality. This raises the question of why the abundance of re-sprouter species is negatively impacted by seeding large legumes. Legume species are $\mathrm{P}$, but not $\mathrm{N}$ limited due to $\mathrm{N}$ fixation, and may respond vigorously to applied $\mathrm{P}$ (e.g. see Table 1). However, many re-sprouter species (including the study species) are generally slow growing (Pate et al. 1990; Bowen 1991). For example, in an experiment in newly restored jarrah forest, Koch et al. (2004) found that while over 22 months $X$. preisii plants were slow growing, plants were twice as heavy when they were not in competition with neighbouring plants. Plants in this experiment also received $80 \mathrm{~kg} \mathrm{P} \mathrm{ha}^{-1}$ suggesting that $X$. preissi is not so much sensitive to high soil $\mathrm{P}$, but sensitive to competition. Consequently, one explanation for the reduced abundance of these species at high $\mathrm{P}$ is simply that they are outcompeted for resources (e.g. water, light or space) by vigorous legume species. An alternative, but not mutually exclusive, hypothesis is that the increased leaf litter accumulation and build-up of fine woody debris once the legume species start to senesce inhibits ongoing germination and seedling establishment of understorey species. Studies are required to determine the relative importance of these two mechanisms.

A P-related decline in abundance of the same three groups of understorey species over two independent trials of 15 and 20 years' duration, has significant practical implications. Alcoa currently propagates and plants a suite of Lomandra species and both Xanthorrhoea gracilis and $X$. preissii into restored sites to increase their abundance. Consequently, our data suggest that the low abundance of these species in restored sites may partially result from the high rates of $P\left(40\right.$ and $\left.80 \mathrm{~kg} \mathrm{ha}^{-1}\right)$ that have been applied as part of previous standard practice. Further, the use of a zero-fertiliser regime and a reduced legume seed mix may 
potentially enable the effort around propagating these species to be reduced whilst still increasing their long-term abundance.

Restoration practitioners aim to achieve a rate of fertiliser application that both compensates for nutrient losses and reflects the aims of restoration. If the aims of restoration are to maximise ground cover (to minimise erosion or maximise productivity), then higher rates of fertiliser application might be needed compared with those that might be used to maximise floristic diversity. While these trade-offs between these goals are not unique to mine site restoration (e.g. Catterall et al. 2005) our current data indicate that this trade-off is not necessarily straightforward. While applying $P$ and seeding large understorey legumes increased understorey productivity at five years of age, this was not the case after 15 years (Experiment 2). After 15 years, the treatment that resulted in the greatest level of understorey cover was counter intuitively the no large legume, $0 \mathrm{~kg} \mathrm{P} \mathrm{ha-1}$ fertiliser treatment. Indeed, in another study of this experiment, this was also the treatment that maximised species richness at 15 years of age (Daws et al. 2019). This suggests that whilst seeding legumes and applying P fertiliser results in high initial cover, once the legumes start to senesce, the resulting niche space that they leave remains largely unfilled except by legume recruits.

\section{Conclusion}

These data suggest that to re-establish a diverse plant community following mining in the jarrah forest, minimising initial competition from vigorous understorey legumes by manipulating the applied seed mix and applying minimal or zero fertiliser may be appropriate. Whilst this strategy does not maximise initial plant cover and productivity, over the longer term it maximises understorey plant cover, the abundance of a suite of re-sprouter species (this study; Daws et al. 2019) and species richness (Daws et al. 2019). Further studies of the effects of fertiliser application rates on re-establishing a diverse plant community in regions with soils naturally deficient in nutrients are required to assess the generality of these results.

\section{Acknowledgement}

MI Daws is a former and AH Grigg a current, paid employee of Alcoa of Australia Ltd. This work was part funded by the Australian Research Council. We acknowledge the work of John Koch and Melanie Norman in earlier studies cited here and thank various Alcoa employees for technical assistance.

\section{References}

Australian Bureau of Meteorology 2015, Monthly Climate Statistics for Dwellingup, Melbourne, viewed November 2015, http://www.bom.gov.au/climate/averages/tables/cw_009538.shtml

Banning, NC, Grant, CD, Jones, DL \& Murphy, DV 2008, 'Recovery of soil organic matter, organic matter turnover and nitrogen cycling in a post-mining forest rehabilitation chronosequence', Soil Biology and Biochemistry, vol. 40, pp. 2021-2031.

Bell, DT 2001, 'Ecological response syndromes in the flora of southwestern Western Australia: fire resprouters versus reseeders', Botanical Review, vol. 67, pp. 417-440.

Bowen, BJ 1991, Fire Response Within the Family Proteaceae: A Comparison of Plants Displaying the Seeder and Resprouter Mode of Recovery, PhD thesis, The University of Western Australia, Perth.

Boyes, LJ, Gunton, RM, Griffiths, ME \& Lawes, MJ 2011, 'Causes of arrested succession in coastal dune forest', Plant Ecology, vol. 212, pp. 21-32.

Bradshaw, AD 1983, 'The reconstruction of ecosystems', Journal of Applied Ecology, vol. 20, pp. 1-17.

Brady, CJ \& Noske, RA 2010, 'Succession in bird and plant communities over a 24-year chronosequence of mine rehabilitation in the Australian monsoon tropics', Restoration Ecology, vol. 18, pp. 855-864.

Catterall, CP, Kanowski, J, Lamb, D, Killin, D, Erskine, PD \& Wardell-Johnson, G 2005, 'Trade-offs between timber production and biodiversity in rainforest plantations: emerging issues and an ecological perspective', in PD Erskine, D Lamb \& M Bristow (eds), Reforestation in the Tropics and Subtropics of Australia: Using Rainforest Tree Species, Rural Industries Research and Development Corp, Barton, pp. 206-221.

Colwell, JD 1963, 'The estimation of the phosphorus fertilizer requirements of wheat in southern New South Wales by soil analysis', Australian Journal of Experimental Agriculture and Animal Husbandry, vol. 3, pp. 190-197.

Daws, MI, Standish, RJ, Koch, JM \& Morald, TK 2013, 'Nitrogen and phosphorus fertiliser regime affect jarrah forest restoration after bauxite mining in Western Australia', Applied Vegetation Science, vol. 16, pp. 610-618.

Daws, MI \& Koch, JM 2015, 'Long-term restoration success of re-sprouter understorey species is facilitated by protection from herbivory and a reduction in competition', Plant Ecology, vol. 216, pp. 565-576. 
Daws, MI, Standish, RJ, Koch, JM, Morald, TK, Tibbett, M \& Hobbs, RJ 2015, 'Phosphorus fertilisation and large legume species affect jarrah forest restoration after bauxite mining', Forest Ecology and Management, vol. 354, pp. 10-17.

Daws, MI, Grigg, AH, Tibbett, M \& Standish, RJ 2019, 'Enduring effects of large legumes and phosphorus fertiliser on jarrah forest restoration 15 years after bauxite mining', Forest Ecology and Management, vol. 438, pp. 204-214.

de Campos, MCR, Pearse, SJ, Oliveira, RS \& Lambers, H 2013, 'Downregulation of net phosphorus-uptake capacity is inversely related to leaf phosphorus-resorption proficiency in four species from a phosphorus-impoverished environment', Annals of Botany, vol. 111, pp. 445-454.

Garcia-Palacios, P, Soliveres, S, Maestre, FT, Escudero, A, Castillo-Monroy, AP \& Valladares, F 2010, 'Dominant plant species modulate responses to hydroseeding, irrigation and fertilization during the restoration of semiarid motorway slopes', Ecological Engineering, vol. 36, pp. 1290-1298.

Gardner, JH \& Bell, DT 2007, 'Bauxite mining restoration by Alcoa World Alumina Australia in Western Australia: social, political, historical, and environmental contexts', Restoration Ecology, vol. 15, pp. S3-S10.

Gough, MW \& Marrs, RH 1990, 'A comparison of soil fertility between semi-natural and agricultural plant-communities - implications for the creation of species-rich grassland on abandoned agricultural land', Biological Conservation, vol. 51, pp. 83-96.

Grant, CD, Ward, SC \& Morley, SC 2007, 'Return of ecosystem function to restored bauxite mines in Western Australia', Restoration Ecology, vol. 15, pp. S94-S103.

Grime, JP 1979, Plant Strategies and Vegetation Processes, John Wiley \& Sons, Chichester.

Handreck, KA 1991, 'Interactions between iron and phosphorus in the nutrition of Banksia ericifolia L. f. var. ericifolia (Proteaceae) in soil-less potting media', Australian Journal of Botany, vol. 39, pp. 373-384.

Hingston, FJ, Malajcsuk, N \& Grove, TS 1982, 'Acetylene reduction ( $\mathrm{N}_{2}$-fixation) by jarrah forest legumes following fire and phosphate addition', Journal of Applied Ecology, vol. 19, pp. 631-645.

Holmes, PM 2001, 'Shrubland restoration following woody alien invasion and mining: effects of topsoil depth, seed source, and fertilizer addition', Restoration Ecology, vol. 9, pp. 71-84.

John, R, Dalling, JW, Harms, KE, Yavitt, JB, Stallard, RF, Mirabello, M, Hubbell, SP, Valencia, R, Navarrete, H, Vallejo, M \& Foster, RB 2007, 'Soil nutrients influence spatial distributions of tropical tree species', Proceedings of the National Academy of Sciences of the United States of America, vol. 104, pp. 864-869.

Koch, JM 1987, 'Nitrogen accumulation in a rehabilitated bauxite-mined area in the Darling Range, Western Australia', Australian Forestry Research, vol. 17, pp. 59-72.

Koch, JM, Richardson, J \& Lamont, BB 2004, 'Grazing by kangaroos limits the establishment of the grass trees Xanthorrhoea gracilis and $X$. preisii in restored bauxite mines in eucalypt forest of southwestern Australia', Restoration Ecology, vol. 12, pp. 297-305.

Koch, JM 2007, 'Restoring a jarrah forest understorey vegetation after bauxite mining in Western Australia', Restoration Ecology, vol. 15, pp. S26-S39.

Lambers, H, Juniper, D, Cawthray, GR., Veneklaas, EJ \& Martinez-Ferri, E 2002, 'The pattern of carboxylate exudation in Banksia grandis (Proteaceae) is affected by the form of phosphate added to the soil', Plant and Soil, vol. 238, pp. 111-122.

Lambers, H, Raven, JA, Shaver, GR \& Smith, SE 2008, 'Plant nutrient-acquisition strategies change with soil age', Trends in Ecology and Evolution, vol. 23, pp. 95-103.

Langkamp, JP, Swinden, LB \& Dalling, MJ 1979, 'Nitrogen fixation by Acacia pellita on areas restored after mining at Groote Eylandt, Northern Territory', Australian Journal of Botany, vol. 27, pp. 353-361.

Le Stradic, S, Buisson, E, Negreiros, D, Campagne, P \& Fernandes, GW 2014, 'The role of native woody species in the restoration of Campos Rupestres in quarries', Applied Vegetation Science, vol. 17, pp. 109-120.

Lockley, IR \& Koch, JM 1996, 'Response of two eucalypt species to fertiliser application on rehabilitated bauxite mines in Western Australia', Environmental Research Bulletin No .27, Alcoa of Australia Ltd, Pinjarra.

Norman, MA, Koch, JM, Grant, CD, Morald, TK \& Ward, SC 2006, 'Vegetation succession after bauxite mining in Western Australia', Restoration Ecology, vol. 14, pp. 278-288.

Ortiz, O, Ojeda, G, Espelta, JM \& Alcaniz, JM 2012, 'Improving substrate fertility to enhance growth and reproductive ability of a Pinus halepensis Mill. Afforestation in a restored limestone quarry', New Forests, vol. 43, pp. 365-381.

Parrotta, JA \& Knowles, OH 1999, 'Restoration of tropical moist forests on bauxite mined lands in the Brazilian Amazon', Restoration Ecology, vol. 7, pp. 103-116.

Parrotta, JA \& Knowles, OH 2001, 'Restoring tropical forests on lands mined for bauxite: examples from the Brazilian Amazon', Ecological Engineering, vol. 17, pp. 219-239.

Pate, JS, Froend, RH, Bowen, BJ, Hansen, A \& Kuo, J 1990, 'Seedling growth and storage characteristics of seeder and resprouter species of Mediterranean-type ecosystems of S.W. Australia', Annals of Botany, vol. 65, pp. 585-601.

Prober, SM \& Wiehl, G 2012, 'Relationships among soil fertility, native plant diversity and exotic plant abundance inform restoration of forb-rich eucalypt woodlands', Diversity and Distributions, vol. 18, pp. 795-807.

Rayment, GE \& Higginson, FR 1992, Australian Laboratory Handbook of Soil and Water Chemical Methods, Inkata Press, Melbourne.

Shane, MW, Szota, C \& Lambers, H 2004, 'A root trait accounting for the extreme phosphorus sensitivity of Hakea prostrata (Proteaceae)', Plant Cell and Environment, vol. 27, pp. 991-1004.

Short, TA, Menzies, NW \& Mulligan, DR 2000, 'Mining disturbance alters phosphorus fractions in northern Australian soils', Australian Journal of Soils Research, vol. 38, pp. 411-421.

Soliveres, S, Monerris, J \& Cortina, J 2012, 'Irrigation, organic fertilization and species successional stage modulate the response of woody seedlings to herbaceous competition in a semi-arid quarry restoration', Applied Vegetation Science, vol. 15, pp. 175-186. 
Spain, AV, Hinz, DA, Ludwig, JA, Tibbett, M \& Tongway, DJ 2006, 'Mine closure and ecosystem development-Alcan Gove Bauxite Mine, Northern Territory, Australia', in AB Fourie \& M Tibbett, (eds), Proceedings of the First International Seminar on Mine Closure, Australian Centre for Geomechanics, Perth, pp. 299-308.

Spain, AV, Tibbett, M, Hinz, DA, Ludwig, JA \& Tongway, DJ 2015, 'The mining restoration system and ecosystem development following bauxite mining in a biodiverse environment of the seasonally dry tropics, Northern Territory, Australia', in M Tibbett (ed.), Mining in Ecologically Sensitive Landscapes, CRC Press, Netherlands, pp. 159-227.

Standish, RJ, Morald, TK, Koch, JM, Hobbs, RJ \& Tibbett, M 2008, 'Restoring jarrah forest after bauxite mining in Western Australia: the effect of fertiliser on floristic diversity and composition', in AB Fourie, M Tibbett, IM Weiersbye, PJ Dye (eds), Proceedings of the Third International Seminar on Mine Closure, Australian Centre for Geomechanics, Perth, pp. 717-725.

Standish, RJ, Tibbett, M, Vlahos, S, Stokes, BA \& Hobbs, RJ 2010, 'Effect of fertiliser on early-successional jarrah forest restored after bauxite mining in south-western Australia', in AB Fourie, M Tibbett, \& J Wiertz (eds), Proceedings of the Fifth International Conference on Mine Closure, Australian Centre for Geomechanics, Perth, pp. 387-396.

Standish, RJ, Daws, MI, Gove AD, Didham, RK, Grigg, AH, Koch, JM \& Hobbs, RJ 2015, 'Long-term data suggest jarrah-forest establishment at restored mine sites is resistant to climate variability', Journal of Ecology, vol. 103, pp. 78-89.

Todd, MVL, Adams, MA \& Grierson, PF 2000, 'Mineralisation of nitrogen in a chronosequence of rehabilitated bauxite mines', Australian Journal of Soil Research, vol. 38, pp. 435-451.

Ward, SC, Koch, JM \& Nichols, OG 1990, 'Bauxite mine rehabilitation in the Darling Range, Western Australia', Proceedings of the Ecological Society of Australia, vol. 16, pp. 557-565.

Wassen, MJ, Venterink, HO, Lapshina, ED \& Tanneberger, F 2005, 'Endangered plants persist under phosphorus limitation', Nature, vol. 437, pp. 547-550.

Williamson, JC, Rowe, EC, Hill, PW, Nason, MA, Jones, DL \& Healey, JR 2011, 'Alleviation of both water and nutrient limitations is necessary to accelerate ecological restoration of waste rock tips', Restoration Ecology, vol. 19, pp. 194-204.

Zipper, CE, Burger, JA, McGrath, JM, Rodrigue, JA \& Holtzman, GI 2011, 'Forest restoration potentials of coal-mined lands in the eastern United States', Journal of Environmental Quality, vol. 40, pp. 1567-1577. 
